\title{
Building Brand Equity through the Influence of Corporate Social Responsibility (CSR): A Case Study of Hollard Insurance- Kumasi
}

\author{
Daniels Reese Mensah \\ Hollard Insurance Company, Kumasi - Ghana \\ P. O. Box 1481, Kumasi-Ghana \\ E-mail: ReeseD@hollard.com.gh \\ Joseph Yensu (Corresponding author) \\ Institute of Entrepreneurship and Enterprise Development \\ Department of Entrepreneurship and Finance, Kumasi Polytechnic, Kumasi- Ghana \\ PO Box 854, Kumasi, Ghana \\ Tel: +233-(0)50-5604383Ｅ-mail: joseph.yensu123@gmail.com
}

Daniel Abayaakadina Atuilik

Kwame Nkrumah University of Science and Technology, Kumasi

PMB, Kumasi, Ghana

Tel: 233-(0)24-960-2121Ｅ-mail: datuilik@yahoo.com

Received: Nov. 2, 2016

Accepted: Nov. 27, $2016 \quad$ Published: January 1, 2017

doi:10.5296/jmr.v9i1.10108

URL: http://dx.doi.org/10.5296/jmr.v9i1.10108

\begin{abstract}
Corporate Social Responsibility (CSR) is an important part of every business entity and as such has been described as a tool to build the brand equity of a business. Thus, understanding its implications help firms to build their brand equity. Therefore, this study investigates into building brand equity through the influence of CSR in Hollard Insurance Company, Kumasi. Questionnaires were designed and administered to a sample of 373 employees and customers
\end{abstract}


of the Hollard Insurance Company. The data collected were analysed using descriptive statistics, cronbach alpha and multiple regression. The study shows that all CSR variables influence Brand Equity. However, Legal, Ethical, Voluntary and aggregated Corporate Social Responsibility significantly influence Brand Equity, with positive relationships. Ethical Responsibility was found not to be significant, but had a positive influence on Brand equity. The findings suggest that with Hollard Insurance commitments to legal, ethical and voluntary responsibility; they can present better view of their services by considering the CSR and include a positive brand association of their name in people's minds. It was further suggested that Hollard Insurance Company should review its CSR to assess the quality of legal, ethical and voluntary responsibilities to determine whether they are effectively carried out.

Keywords: Brand, Brand equity, Corporate social responsibility, Hollard Insurance, Ghana 


\section{Introduction}

Corporate Social Responsibility (CSR) programs are increasing tremendously in significance and are considered for the prescription of ethical businesses. Reason for the broadness of the subject matter is that firms' behaviors have changed, the more dominant because customers, investors and other stakeholders want a bigger transparency of businesses.

The implementation of corporate social responsibility policies generates a trusting relationship which enables stakeholders' commitment to the organization via actions such as supplier investments, customer loyalty and stockholder capital investments (Maignan \& Ferrell, 2004). In the world marketplace, the firm's environmental and social track records and the treatment of employees are considered as significant trust issues.

Today's businesses are witnessing avoidance by consumers of what is perceived as socially irresponsible products of companies that have allegedly not acted in the society's best interest. Equally poor social performance will end up in driving away potential investors. Issues of litigations between communities and companies continue to increase as a result of lack of societal responsibilities which leads to the closure of firms. An example of such firms is Nuru Kente Company, manufacturers of Kente cloths at Atonsu in Kumasi. The treatment of their raw materials was full of pollution to the environment. The residents of that community took the company on and before they could realize the company is out of operation.

Most organisations do not see the importance of indulging in Corporate Social Responsibility because they think it is a waste of valuable resources such as time and money. They do not envisage how their involvement in CSR could have an impact on the value of the service or product. Several other companies have also not realized how communicative CSR could be as in opposition to another ever explosive communication tool. Actions towards responsible branding and corporate social responsibility have been taken into account in many companies, but it is not clear how insurance consumers perceive those activities.

With regards to literature, a number of studies have been done globally in the more developed economies on various aspects of CSR; most researchers to date on CSR have focused on other business institutions like Banks, Telecommunication Companies, SME's. However, in Ghana the literature on CSR/ Brand Equity concerning insurance industries is unknown since as far as it is known no study has been conducted in this area. This gives the justification for this research to be conducted to help bridge the literature gap existing. The study sees a problem with the building of brand equity among the insurance industries through CSR and therefore brings to fore the Building of Brand Equity through the influence of CSR in Hollard Insurance Company.

The rational for the study is therefore to explore how a company's corporate social responsibility (CSR) activities influences brand equity in the insurance industry. The study focused on the customer perspective onresearching brand equity. Specifically, the study aims to;

1. To establish the influence of Economic Responsibility on Brand Equity in Hollard Insurance Company. 
2. To ascertain the influence of Legal Responsibility on Brand Equity in Hollard Insurance Company.

3. To determine the influence of Ethical Responsibility on Brand Equity in Hollard Insurance Company.

4. To establish the influence of Voluntary Responsibility on Brand Equity in Hollard Insurance Company.

5. To determine the influence of aggregated CSR on Brand Equity in Hollard Insurance.

The rest of the paper is organized as follows; literature review, methodology, the results of the study and finally, findings, conclusion and recommendations.

\section{Literature Review}

\subsection{Theoretical Review}

CSR can be defined as situations where the company goes beyond compliance and engages in actions that appear to further some social good, beyond the interest of the company and that which is required by law (McWilliams \& Siegel, 2000). The term CSR was first coined in the 1950s and it gained peculiar attention in management studies in the 1970s. Predominantly, the activities under the umbrella of CSR fall into three categories: economic growth, ecological balance and social progress.

The accepted influence of CSR involves its impact on organizational Financial Performance (FP) and social performance. In the case of CSR, the literature indicates two schools of thought that predominantly debate and describe a business' primary activity as profit maximization or business, society interaction for the welfare of society (Carroll, 1997). However, the construct has been related to many aspects of a business, such as stakeholder expectations, increasing social performance/ FP and compliance with government regulations (Griffin and Mahon, 1997). Sharp and Zaidman (2009) studied CSR from a strategic perspective and concluded that incorporation of CSR into a company's strategic management process can yield better outcomes for organizations.

The dominant paradigm about the proponents of CSR earliest starts from the work of Carroll, 1997 who has described the range of activities included in the CSR from philanthropic activities till larger social benefits. According to Carroll, companies are expected to generate profits, obey the law, operate in line with social norms and do well in society beyond the society' s expectations

Branco and Rodingues (2006) described CSR as an important resource for organizations from a resource-based perspective. According to Barney (1991), organizations can capitalize on their unique resources for sustainability, whereas the resources should meet the criteria of resource-based view (RBV), that is, they should be valuable, inimitable, rare and immobile. CSR can help an organization build such unique resources as reputation, employee capabilities, and knowledge and network of relationships. Oliver (1997) also defined strategic use of CSR from an institutional and resource-based perspective to achieve sustainability in 
the organizations. On the basis of previous literature, the research divides CSR into two dimensions: external CSR practices and internal CSR practices.

The most common operationalization of CSR has been done in the work of Carroll, (1991) who provides the foundational concepts of CSR. The firm's CSR practices should encompass its economical, legal, ethical and voluntary activities for social responsibility, whereas more and more emphasis is only on the voluntary practices that may include philanthropy, corporate volunteers and corporate citizenship (Putnam, 1993)

Researchers have also documented an internal dimension of CSR that generally covers the employees' well-being at work, particularly, including their health and safety besides development and talent identification (Fuentes-Garcí et al., 2008). Another addition to the dimensions of CSR is the 2001 Green Paper from the Commission of European Communities that identifies the typology of CSR as its internal and external dimensions.

Generally, research in social responsibility has focused on only the external CSR, that is, community development and environmental protection, but and literature are lacking in the internal dimension of CSR and the link between these two. According to Carroll, (1991), the dimensions of CSR can be;

$>$ Economic value which entails entailing a good return on investment for the owners and shareholders, creating jobs and fair pay for workers, and making developments in business.

$>$ Legal; that is to obey the rules of business and to govern the business according to government legislation.

$>$ Ethical; that is, being moral and doing just and fair things. Such responsibility is rooted in humanitarian concerns.

$>$ Volunteerism; where a firm has a wide scope of discretionary behaviors by performing certain activities by which they are actually contributing to the welfare of society.

$>$ Nondiscrimination and Equal Employment Opportunity

$>$ Protection of Human Rights

$>$ Managing Environmental Impacts

\subsubsection{CSR from Stakeholders' Perspective}

CSR has also been viewed from the perspective, where the stakeholders' dimensions are used as dimensions of CSR (employees, shareholders, customers, suppliers, communities, and natural environment.). A firm's survival and success depends on the ability of its managers to create sufficient wealth and satisfaction of its primary stakeholders (Clarkson, 1995). Primary stakeholders of a firm include employees, shareholders, customers, suppliers, communities, and natural environment. If any of the primary stakeholder groups withdraws its support of the firm, the firm's operation is adversely affected (Clarkson, 1995). Firms that establish relationship with primary stakeholders beyond market transactions gain competitive advantage (Barney and Hansen, 1994; Fomburn and Shanley, 1990). Effective management 
of key stakeholders acts as a value driver by leveraging performance and reducing stakeholder-inflicted costs. Lower employee turnover reduces hiring and training costs, loyal suppliers, reduce quality certification costs, supportive communities reduce legal and public relations overhead, and stable shareholders reduce stock market volatility (McVea and Freeman, 2005). In order to achieve sustainability in business, firms must identify key stakeholders affecting the firm, identify their needs, and design organizational policies and practices to cater for them. Accordingly CSR is defined towards a particular stakeholder group as a firm's policy, processes, and practices towards that stakeholder group.

\subsubsection{The Brand Equity Concept}

Brand equity refers to the value built up in a brand over time, made up of both functional attributes, tangible and intangible attributes. Equity when it comes to brand equity is perceived as superior. Higher equity is an indication of higher loyalty. Brand equity is usually in the minds of consumers, who normally carry a fair but complicated set of assumptions and beliefs about their roles (Holbrook, 1987). Aker(1991) also see brand equity as the value that consumers associate with a product and it is usually the consumer's perception about the overall superiority of a product, carrying the brand name in comparison to other brands. In accordance with Lasser et al., 1995 brand equity is the consumer's perception and not any objective indicators.

In the general sense, a lot of advantages have been brought up from brand equity to effective marketing, the ability to effect changes in premiums and larger margins, possibilities to achieve successful brand extensions, the resistance against competitor's promotion, less vulnerability to competitive marketing actions or marketing crises and the creation of barriers against competitive entries (Keller, 2003).

In light of sources of brand equity, a lot of dimensions appear in several frameworks. Keller, (1993) is the most persistently referred in this area of research. They brought out brand equity in four dimensions; loyalty, associations, loyalty and awareness. Keller made a rough outline and discusses brand equity in line of image and awareness. According to Aker (1991), customer-based brand equity is measured by five dimensions of brand equity, such as; Brand Awareness, Brand Associations, Product Associations, Perceived Quality and Brand Loyalty. Both Keller and Aaker brought out the significance of brand awareness, and as well view this dimension as a basis to strong brands. The quality aspect is as good in both frameworks, coupled with the differences Aaker discussed in an explicit manner, while Keller sees the perceived quality as part of the brand image, formulated on a more abstract level through the attributes and benefits and terms.

Aspects related to the association or image are also apparent in both frameworks, with the difference that Keller's definition is considerably wider, as it includes all perceptions about a brand as reflected by the brand associations held in consumer memory. The one aspect disuniting the framework is the view on brand loyalty. While Aaker considered a loyalty to be a determinant of brand equity, Keller saw it as a result of a strong brand. Judging by the empirical research from the last decade, Aakers view on brand equity has come to dominate the empirical research, perhaps because his framework is more practically useful and more easily operationalized and measured. 
The research on brand equity is gaining and increasing popularity as some researchers have concluded that brands are of the most charitable assets that companies possesses. High brand equity levels are known to result to higher consumer preferences and intentions (Cobb-Walgren et al., 1995). Also, corporate social responsibility is also another tool; by which firms used to enhance their corporate image.

\subsection{Empirical Review}

In the past, financial performance was the major criterion to evaluate a firm's value. Higher ranks were given to firms that provide greater margins financially. Maximization of shareholders 'wealth was, by far, the focal point of profit-driven organizations. In this regard, the emphasis on CSR in the past was not evident. In this decade, however, the perception about CSR has changed significantly (Aasad, 2010). The success of a company is now also being measured by its contribution to society (Pokorny, 1995; Saunders, 2006). Through CSR, individualistic and unscrupulous business behavior can be prevented (Pakseresht, 2010).

In a study by Hoeffler and Keller, (2002) on "Building Brand Equity through Corporate Societal Marketing", the authors describe six means by which CSM programs can build brand equity: (1) building brand awareness, (2) enhancing brand image, (3) establishing brand credibility, (4) evoking brand feelings, (5) creating a sense of brand community, and (6) eliciting brand engagement. The authors also address three key questions revolving around how CSM programs have their effects, which cause the firm should choose, and how CSM programs should be branded. The results identified through hypothesis that Co-branding through a CSM program is most appropriate as a means to complement the brand image with the specific associations leveraged from the cause. Self-branding a CSM program is most appropriate as a means of augmenting existing products and services.

In a study conducted by Saunders (2006), it was found that the percentage of consumers who are more likely to recommend a brand that supports a good cause over the one that does not is $52 \%$. Meanwhile, $55 \%$ of consumers contend that in a recession, they will buy from brands that support good causes even if they are not necessarily the cheapest. Companies that have made CSR a central part of their business are reaping the benefits in the form of company sustainability,

Baker (2001) stated that CSR efforts in an organization can impact society in four main areas, namely, the environment, community, workplace and the marketplace. The author further suggested that these four CSR impact areas are tied to the relevant stakeholder groups for in the organization. The main stakeholders that are impacted by the four CSR impact areas are shareholders, employees and unions, local communities, and the government. The author asserts that in terms of business quality, a company (driven by profits) needs to stamp its impact on the marketplace, workplace, environment, and on the community specifically. This is in addition to its traditional focus on financial imperatives. The author further suggested that a company should develop and execute carefully planned CSR initiatives to distinguish itself as a leader in terms of being a responsible business entity, taking all major shareholder dimensions into perspective, rather than solely focusing on the shareholders 'maximization maxim.

In a study by Ahmadi \& Alipur (2015) on the Effect of Social Responsibility on Brand 
Performance with mediation effect of Equity and the Company's Reputation in the Insurance Industry of Asia. Customers who had the experience of using services of these insurance companies were used as samples and finally 384 questionnaires were used in the analysis of research hypotheses. Data received from clients were analyzed using confirmatory factor analysis and structural equation techniques. LISREL and SPSS were used to approve or reject hypotheses. The study was a survey in terms of data collection and correlational in terms of examining the relationships between variables. According to the results of hypothesis testing, it was observed that the impact of insurance corporate social responsibility on the brand equity, and brand equity on brand performance was approved.

Mishra \& Kharagpur (2010) in a study of the influences of CSR on firm Performance in India used the stakeholders' theory to measure CSR. The stakeholders' variables used include CSR towards Customers, CSR towards Community, CSR towards Investors, CSR towards Environment and CSR towards Employees. It was found out that favorable CSR towards each of the six stakeholders also enhanced the Firm Performance. The study found a positive influence of CSR on firm performance. This was consistent with the study by Turban and Greening (1997) who found out that Higher CSR towards employees in terms of employee-sensitive policies and practices of firms enhances employee productivity, reduces absenteeism, and facilitates recruitment and retention of better quality employees (Turban and Greening, 1997). The study also found out that aggregate and segregate CSR predicting Firm Performance was significant, suggesting that the socially responsible business yielded higher performance of manufacturing firms.

\section{Methodology}

\subsection{Research Design and Sample size}

The research design employed in this study was a survey design. The approach to a research depends on the researcher's philosophical view of the social world. There are four main paradigms guiding the researcher. These are categorised as positivism, interpretivism, critical theory and realism (Healy and Perry, 2000; McMurray, 2008; Neuman, 2006). However the researcher employed the realism, since Realism focuses on the meanings associated with people's perception of reality (Easterby et al., 1991). This makes realities imperfectly and probabilistically apprehensible (Healy and Perry, 2000). Realism research predominantly uses qualitative methods when collecting data and focuses on people's attitudes and socially constructed realities (Easterby et al., 1991; Sobh and Perry, 2005). However, this study employed the quantitative approach. The quantitative approach used in this study permits the researcher to examine respondents' perceptual realities (Ashkanasy et al., 2000) even though it does not enable an analysis of the most profound level of the constructs.

The population for the study was considered as the entire Staff and Customers of Hollard Insurance Company, Kumasi Branch. Since it is impractical to conduct a census (that is, to include everyone in the population) because of constant turnover and resource constraints, a representative sample is chosen from the population (Saunders et al, 2007). Using structured questionnaires, 303 respondents were selected for this study to represent the Staff of Hollard Insurance and its customers. The sample was made up of 30 staff and 273 customers of Hollard Insurance Company. Using staffs and customers of the insurance company was 
considered appropriate since the objectives can be viewed best from the staff as well as the customers. Probability sampling technique specifically, the simple random sampling technique was used to select respondents from each company.

\subsection{Data Analysis}

The statistical package for social science (SPSS) was adopted in processing primary data gathered from the field. A pre-test of the questionnaire was conducted to assess the content validity of the measurement scales using the Cronbach Alpha. A scale item is reliable if the Cronbach alpha value is 0.7 or better. This will be done to know whether the scale items have adequate reliability and deemed appropriate for further analysis.

To be able to analyse the influence of the dimensions of corporate social responsibility (CSR) on building brand equity, a primary data was also used. Brand equity measures for each brand equity dimension are designed considering theoretical and operational definitions and particularities of Aakers customer based brand equity dimensions construct (1991). Each brand quality constructs is measured by original measurement items, which were developed accordingly. This measurement is also in line with the studies of Chiu, Yang, Lai \& Pai (2010) and Dua, Chahal \& Sharma (2013). The brand equity constructs measurement includes Perceived Quality, Brand Awareness, Brand Satisfaction and Brand Loyalty.

To find out how the dimensions of CSR influence building brand equity, a multiple regression analysis technique was used to regress the items under CSR on the average brand equity score. Multiple regression was used because it tests the relative contribution of independent variables on brand equity. Individual measures were ordinal but were averaged to yield the averages for each dimension of the dependent variable. An aggregated CSR (average of the variables of CSR) is also included in the model. The independent variable is the CSR whiles the dependent variable is the brand equity. In equation form, we have:

$$
\mathrm{Y}_{\mathrm{i}}=\beta_{0}+\beta_{1} \mathrm{ECR} \mathrm{i}+\beta_{2} \mathrm{LGR}_{\mathrm{i}}+\beta_{3} \mathrm{ETR}_{\mathrm{i}}+\beta_{4} \mathrm{VLR}_{\mathrm{i}}+\beta_{5} \mathrm{CSR}+e_{\mathrm{i}}
$$

Where; $Y_{\mathbf{i}}$ - Brand Equity, ECR - Economic Responsibility, LGR - Legal Responsibility, ETR -Ethical Responsibility, VRL- Voluntary Responsibility, CSR-aggregated CSR. 
Table 1. Variable Descriptions and Measurement

\begin{tabular}{|c|c|c|c|}
\hline CODE & VARIABLE & & MEASUREMENT \\
\hline ECR & Economic Responsibility & & $\begin{array}{l}\text { Average score of the items of } \\
\text { Economic Responsibility }\end{array}$ \\
\hline LGR & Legal Responsibility & & $\begin{array}{l}\text { Average score of the items of } \\
\text { Legal Responsibility }\end{array}$ \\
\hline ETR & Ethical Responsibility & & $\begin{array}{l}\text { Average score of the items of } \\
\text { Ethical Responsibility }\end{array}$ \\
\hline VLR & Voluntary Responsibility & & $\begin{array}{l}\text { Average score of the items of } \\
\text { Voluntary Responsibility }\end{array}$ \\
\hline CSR & $\begin{array}{l}\text { Aggregated Corporate } \\
\text { Responsibility }\end{array}$ & Social & $\begin{array}{l}\text { Average score of the items of } \\
\text { Corporate Social Responsibility }\end{array}$ \\
\hline $\mathbf{P Q}$ & Perceived Quality & & $\begin{array}{l}\text { Average score of the items of } \\
\text { Perceived Quality }\end{array}$ \\
\hline $\mathbf{B A}$ & Brand Awareness & & $\begin{array}{l}\text { Average score of the items of } \\
\text { Brand Awareness }\end{array}$ \\
\hline BL & Brand Loyalty & & $\begin{array}{l}\text { Average score of the items of } \\
\text { Brand Loyalty }\end{array}$ \\
\hline BAS & Brand Association & & $\begin{array}{l}\text { Average score of the items of } \\
\text { Brand Association }\end{array}$ \\
\hline
\end{tabular}

\section{Results}

\subsection{Socio-Demographic Characteristics of Respondents}

The demographic factors in this study are gender, age and official position of the respondent. From table 4.1, it is evident that most of the respondents are females (126) constituting 55.3\% of the respondents and males constitutes minority of the respondents (102) constituting $44.7 \%$ of the respondents. It is also observed that, most of the respondents $(39.9 \%)$ were in the 26-35 age group whiles the minority of the respondents (4.4\%) was in the 65 and above age group. However, customers with age of 36-45 years were also made up of $32.8 \%$ of the respondents' whiles customers with $46-55$ were also made up of $14.5 \%$ of the respondents. 


\section{Macrothink}

Table 2. Age-Sexes Distribution of Respondents

\begin{tabular}{lccclll}
\hline \multirow{2}{*}{ Age } & \multicolumn{3}{c}{ Sex } & \multicolumn{2}{c}{ Totals } \\
\cline { 2 - 5 } & \multicolumn{3}{c}{ Male } & \multicolumn{2}{c}{ Females } & \\
\cline { 2 - 6 } & Frequency & Percentage & Frequency & Percentage & Frequency & Percentage \\
\hline $\mathbf{1 8 - 2 5}$ & 11 & $10.8 \%$ & 8 & $6.3 \%$ & 19 & $8.4 \%$ \\
$\mathbf{2 6 - 3 5}$ & 38 & $37.3 \%$ & 53 & $42 \%$ & 91 & $39.9 \%$ \\
$\mathbf{3 6 - 4 5}$ & 34 & $33.4 \%$ & 41 & $32.6 \%$ & 75 & $32.8 \%$ \\
$\mathbf{4 6 - 5 5}$ & 16 & $15.6 \%$ & 17 & $13.5 \%$ & 33 & $14.5 \%$ \\
$\mathbf{5 6}$ & 3 & $2.9 \%$ & 7 & $5.6 \%$ & 10 & $4.4 \%$ \\
above & & & & & & \\
\hline Total & $\mathbf{1 0 2}$ & $\mathbf{1 0 0} \%$ & $\mathbf{1 2 6}$ & $\mathbf{1 0 0} \%$ & $\mathbf{2 2 8}$ & $\mathbf{1 0 0 \%}$ \\
\hline
\end{tabular}

Source: Field Survey (2016)

Education is very important for human resource development. A person's level of development can be traced to his educational level. Figure 1 shows that, $7.4 \%$ of the respondents only have a basic level of education and $37.8 \%$ of the respondents had secondary education. However, 54.8\% were graduates from universities, polytechnics, teacher training colleges and other professional tertiary educational institutions, whereas none of the respondents answered for no formal education. This shows the low patronage of insurance among people with abasic level of education, as well as the uneducated.

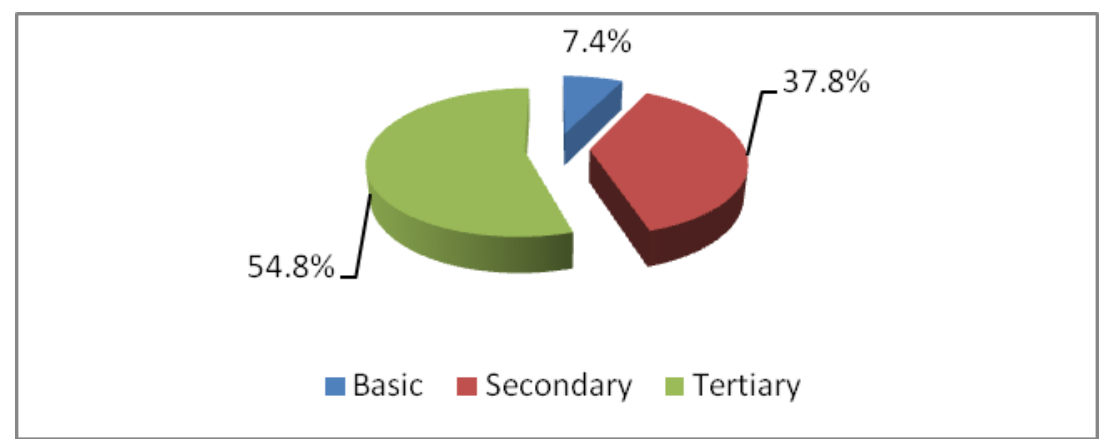

Source: Field Survey, 2016

Figure 1. Educational Status of Respondents

Figure 2 shows that, 15 respondents representing 53.6\% are in the junior staff position whiles 11 representing $39.9 \%$ are in the senior staff position. However, 2 people representing $7.1 \%$ of the staff under study are in the middle management position. This simply means that the respondents are workers at different positions in the organisations and hence a good knowledge on Corporate Social Responsibility and brand equity concerning the hollard insurance company is assured in the study. 


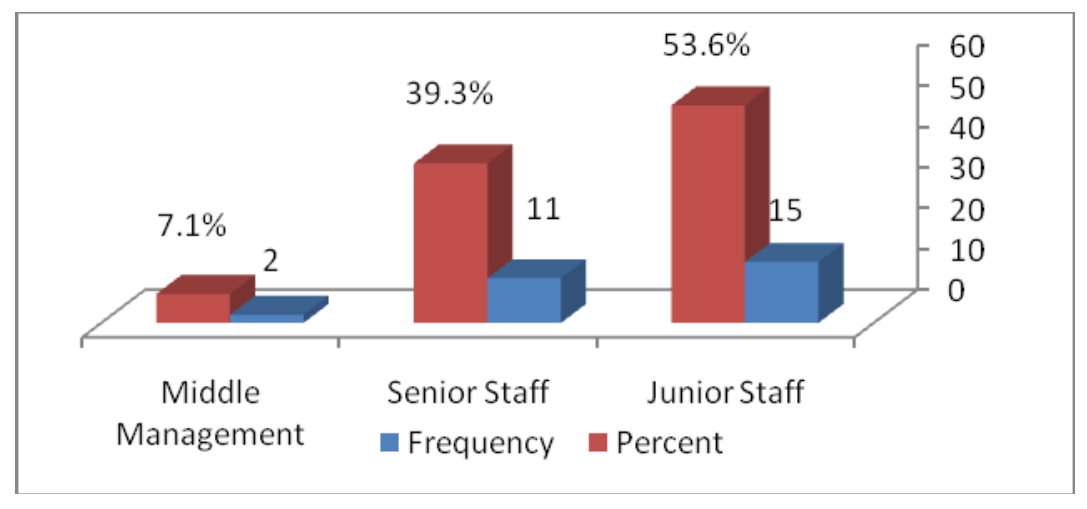

Source: Field Survey (2016)

Figure 2. Position of Respondents (Staff)

\subsection{Descriptive Analysis of the Variables}

Respondents were asked to indicate their perceptions and agreement towards the statement in the questionnaires, using the Five Point Likert-Scale answers. The scale was ranged between $1=$ strongly disagree; to $5=$ strongly agree. Based on their score for each statement, the study had found the average score (mean) for each variable. This value was then categorized to indicate their levels of perceptions towards all variables: 1.00 to $2.25=$ Low, 2.26 to $3.75=$ Moderate and 3.76 to $5.00=$ High

Table 3. Descriptive Analysis of the Variables

\begin{tabular}{llll}
\hline Variables & Mean & Standard Deviation & Level \\
\hline Legal Responsibility & 3.137 & 1.140 & Moderate \\
Economic Responsibility & 3.061 & 0.955 & Moderate \\
Ethical Responsibility & 3.260 & 1.051 & Moderate \\
Voluntary Responsibility & 3.130 & 1.031 & Moderate \\
Aggregated CSR & 3.178 & 0.905 & Moderate \\
\hline
\end{tabular}

Source: Field Survey (2016)SD=Standard Deviation

From Table 4.2, Legal Responsibility, Ethical Responsibility, Voluntary Responsibility, Economic Responsibility and Aggregated CSR variables received (Mean=3.137, SD=1.140), (Mean=3.260, $\mathrm{SD}=1.052), \quad($ Mean=3.130, $\mathrm{SD}=1.031), \quad($ Mean=3.061, $\mathrm{SD}=0.955)$ and (Mean=3.178, $\mathrm{SD}=0.905)$ respectively.

They all hold moderate value of the mean. This indicates a reasonable level of legal responsibility, ethical responsibility, voluntary responsibility, economic responsibility in providing services to the customers. For the aggregated CSR, these variables also received moderate value of means which is (Mean $=3.370, \mathrm{SD}=1.135$ ). Therefore, it is argued here that customers perceived a reasonable level of Customer Relationship.

\subsection{Reliability Analysis}

Cronbach alpha was used to examine the level of reliability of the scale items and Table 4 shows the results. A scale item is reliable if the cronbach alpha value is 0.7 or better. 
Table 4. Reliability of Scale Measures

\begin{tabular}{lll}
\hline DIMENSION & ITEMS & CRONBACH ALPHA \\
\hline CSR & 19 & 0.744 \\
BRAND EQUITY & 14 & 0.732 \\
CSR AND BRAND EQUITY & 33 & 0.788 \\
\hline
\end{tabular}

Source: Field Survey (2016)

Cronbach Alpha of Corporate Social Responsibility is 0.744 which is high and shows that all the elements of Corporate Social Responsibility are internally consistent. Cronbach Alpha of Brand Image is 0.732 which is high and shows that all the elements of Brand Equity are internally consistent. The overall cronbach Alpha is 0.788 which is high and shows the strong internal consistency among both variables. This is consistent with the study of Muhammad Arslan, 2014 on impact of social responsibility on brand image. He concluded that all elements of brand image and social responsibility are internally consistent.

\subsection{Multiple Regression Results of CSR and Brand Equity}

To be able to assess the influence of Economic Responsibility on Brand Equity in Hollard Insurance Company, Legal Responsibility (LGR) and Ethical Responsibility (ETR) on Brand Equity, Voluntary Responsibility (VLR) on Brand Equity, aggregated CSR on Brand Equity; the results are shown in the multiple regression table below.

Table 5. Multiple Regression Results of the Influence of CSR on Brand Equity

\begin{tabular}{lllll}
\hline Brand Equity & Coefficient & Std. Error & T & $\boldsymbol{p}>(\boldsymbol{t})$ \\
\hline ECR & 0.139 & 0.76 & 0.58 & 0.574 \\
LGR & 0.219 & 0.121 & 1.81 & $0.073^{*}$ \\
ETR & 0.235 & 0.128 & -1.83 & $0.070^{*}$ \\
VLR & 0.323 & 0.153 & 2.11 & $0.037^{* *}$ \\
CSR & 0.405 & 0.123 & 0.41 & $0.082^{* *}$ \\
Con & 0.446 & 1.474 & 2.42 & $0.029^{* *}$ \\
\hline
\end{tabular}

\section{Model Diagnostics}

Prob $>0.049,{ }^{* * *}=$ Significant at $1 \% * *=$ Significant at $5 \% *=$ Significant $10 \%$

Source: Field Survey, 2016

ECR - Economic Responsibility, LGR - Legal Responsibility, ETR - Ethical Responsibility, VLR - Voluntary Responsibility, CSR - Aggregated Corporate Social Responsibility.

4.4.1. Influence of Economic Responsibility on Brand Equity in Hollard Insurance Company

A company's first responsibility is it economic responsibility, that is to say, a company needs to be primarily concerned with turning a profit. This is for the simple fact if a company does not make money, it won't last, employees will lose jobs and the company won't even be able to think about taking care of its social responsibilities. Before a company thinks about a good 
corporate citizen, it first needs to make sure that it can be profitable. The study, therefore sorts to find out the influence of economic responsibility as a component of CSR on brand equity.

Table 4.4 displays the influence of dimensions of CSR on Brand Equity. The result shows that, holding all factors that influence Brand equity constant, Economic Responsibility, which is one dimension of CSR is having a positive influence on Brand Equity and is not significant even at $10 \%$. The implication is that an increase in Economic Responsibility (ECR) of Hollard insurance increases Brand Equity by $13.9 \%$. This is consistent with the study by Baker (2001), who found out that economic responsibility is positively related to brand equity.

\subsubsection{Influence of Legal Responsibility on Brand Equity in Hollard Insurance Company}

A company's legal responsibility refers to the requirements that have been placed on it by law. Next to ensuring that the company obeys all laws and becomes profitable is the most significant responsibility, according to the corporate social responsibility theory. Legal responsibility can range from securities regulations to labour law, environmental law and even criminal law. The study, therefore sorts to find out the influence of legal responsibility on brand equity.

Table 5 displays the influence of dimensions of Legal Responsibility on Brand Equity. Legal Responsibility, which is one dimension of CSR is positively related to Brand Equity and is significant at $10 \%$. The implication is that an increase in Legal Responsibility (LGR) increases the Brand Equity by $21.9 \%$. Thus an increase in the adherence to laws placed on Hollard insurance as well as ensuring that the company is profitable is likely to increase the favourability of its brand by insurers. This is consistent with the study of Jian, ZhiJian and Yongji (2000), who concluded that performing of laws has significant positive impact on brand equity.

\subsubsection{Influence of Ethical Responsibility on Brand Equity in Hollard Insurance Company}

Corporate Social Responsibility in simple terms also means that organisations have an ethical responsibility that moves above their economic responsibilities. Ethical responsibilities are responsibilities that a company places on itself because its owners believe it is the right thing to do, and not because they have an obligation to do so. The study, therefore, found out the influence of ethical responsibility on in brand equity.

The result shows that, holding all factors that influence Brand equity constant, Ethical Responsibility as one dimension of CSR has a positive influence on Brand Equity and is significant at $10 \%$. The implication of this is that an increase in Legal Responsibility (LGR) increases the Brand Equity by $23.5 \%$. Thus, if Hollard insurance company increases the responsibilities that it puts on itself because the owners believe it's the right thing to do, then it is likely to increase the favourability of its brand. As a customer's subjective and intangible appraisal of the brand over and above its value, brand equity is impacted by brand awareness, attitude toward the brand, and corporate ethics (Kumar and George, 2007). The findings from the study is consistent with the study of Turban and Greening (1997), who found ethical responsibilities towards employees to have a positive relationship with Corporate Social 
Responsibility. This is also consistent with the study of Leone et al. (2006), who concluded that customer perception of brand ethics is one of the key drivers of brand equity. Leone et al. (2006) also concluded that ethical CSR as an approach to brand ethics will contribute to the development of brand equity. Fan (2005) also concluded that an ethical brand augments the company's reputation and such a reputation reinforces the brand in turn.

\subsubsection{Influence of Voluntary Responsibility on Brand Equity in Hollard Insurance Company}

If a company is able to meet all of its other responsibilities, it can now begin meeting philanthropic or voluntary responsibilities. Philanthropic responsibilities are responsibility that goes above and beyond what is right. They involve making an effort to benefit society, for example, by donating services to community organisations, engaging in projects to aid the environment or donating money to charitable causes. This study, therefore looked at the influence of Voluntary Responsibility on Brand Equity in Hollard Insurance Company.

The result shows that, holding all factors that influence Brand equity constant, Voluntary Responsibility (VLR) is having a positive influence on Brand Equity and is significant at 5\%. The implication of this is that an increase in Voluntary Responsibility leads to $44.6 \%$ increase in Brand Equity. This means that Hollard Insurance indulgent in voluntary responsibilities has a very good influence on the favorability of its brand image. This result confirms the prior study of Zaman (2014), who concluded in his study that if corporation indulge in ethical responsibilities it has a very good influence on the favorability of brand image.

\subsubsection{Influence of Aggregated CSR on Brand Equity in Hollard Insurance Company}

The result shows that, holding all factors that influence Brand Equity constant, Aggregated CSR is positively related to Brand Equity and is significant at $10 \%$. The implication of this is that an increase in Aggregated CSR increases the Brand Equity by $23.5 \%$. The possible explanation for this finding is that the customers often look to CSR indications so as to respond favorably to the Insurance Company. This result confirms prior studies showing that CSR affects firm performance (e.g., Luo \& Bhattacharya, 2006; Margolis \& Walsh, 2003; Orlitzky et al., 2003).

This study is also consistent with the study of Ahmadi \& Alipur, (2015), who found out that impact of corporate social responsibility and the impact of brand equity on brand performance was approved. This is also consistent with the study by Hoeffler and Keller, (2002) as well as Zaman (2014). It is also consistent with the study by Ahmadi \& Alipur, (2015) who found out that insurance company social responsibility has significant positive impact on brand equity. Studies by Jian, ZhiJian and Yongji (2000), also concluded that performing of social development responsibility has no significant positive impact on brand equity.

\section{Summary of Findings, Conclusion and Recommendation}

\subsection{Summary of Key Findings}

The main purpose of this study is to analyse the influence of Corporate Social Responsibility on Brand Equity in Hollard Insurance Company, Kumasi branch. Three hundred and thirty 
respondents were used for the study; comprising of 30 staff members and 273 customers of Hollard Insurance Company. However out of the 30 staff members 27 were retrieved whiles out of the 273 customers 200 were retrieved. The majority of the respondents were males representing $33.4 \%$ whiles the rest of the respondents were females representing $32.6 \%$. Out of the 230 respondents the number of people who had a basic level of education represents $7.4 \%$ of the respondents. High or vocational graduates represent $37.8 \%$, whereas tertiary graduates represent $54.8 \%$.

In analysing the reliability of scale measures, the cronbach alpha showed that all reliability measures with the exception of Voluntary Responsibility was not reliable. However, according to Garson (2002), the Cronbach Alpha increases when the number of items in the scale is increased.

In the multiple regression model of the various determinants of Corporate Social Responsibility as well as the Aggregated CSR and Brand Equity, it was realized that Legal Responsibility, Ethical Responsibility and Voluntary Responsibility are the dimensions of Corporate Social Responsibility which significantly influence Brand Equity showing that these dimensions are good predictors of Brand Equity. It was revealed that three out of the five dimensions under study were significant at ten and five significance level.

\subsection{Conclusion and Recommendation}

Since majority of the predictive variables of the Corporate Social Responsibility variables can influence the Brand Equity of Hollard Insurance Company, Kumasi branch, it is recommended that where the objective of implementing CSR is to improve Brand Equity, then those predictive variables should be the bedrock of that implementation.

Secondly, Hollard Insurance can better present their services by considering the social responsibility and include a positive brand association of their name in people's minds.

Thirdly, there must be constant monitoring and review of the company's responsibilities to assess the quality of Legal, ethical and voluntary responsibilities to determine whether they are effectively carried out. In other words Management of Hollard Insurance should focus on monitoring efforts on CSR.

Fourthly, efforts should be made to intensify their economic values based on social responsibility to create a positive attitude in the minds of their clients.

In conclusion, despite the knowledge this research has provided regarding the extent of influence of CSR on brand equity in Hollard Insurance Company-Kumasi, it does not address all the issues pertaining to CSR in the insurance industry in Ghana. It is therefore recommended that further research be carried by considering a more sample size in the country.

\section{References}

Aaker, D. A. (1991). Managing brand equity: capitalizing on the value of a brand name. NY: The Free Press. 
Asaad, A. (2010). The role of brand equity in the effects of corporate social responsibility on consumer loyalty. Unpublished master's diss, UniversitiSains Malaysia, Malaysia.

Ashkanasy, Neal M., Lyndelle E., Broadfoot, \& Falkus S. A. (2000). Questionnaire measures of organizational culture, 131-145.

Baker, J. (2001). Remarks of Jim Baker, International Confederation of Free Trade Unions, to Organisation for Economic Co-operation and Development. In Conference on Corporate Social Responsibilties, Paris, France (Vol. 19).

Barney, J. (1991). Firm resources and sustained competitive advantage. Journal of management, 17(1), 99-120. https://doi.org/10.1177/014920639101700108

Barney, J. B., \& Hansen, M. H. (1994). Trustworthiness as a source of competitive advantage. Strategic management journal, 15(S1), 175-190. https://doi.org/10.1002/smj.4250150912

Branco, M., \& Rodrigues, L. (2006) Corporate social responsibility and resource-based perspectives. Journal of Business Ethics 69(2), 111-132. https://doi.org/10.1007/s10551-006-9071-z

Carroll, A. B. (1991). The Pyramid of Corporate Social Responsibility: Toward the Moral Management of Organizational Stakeholders. Business Horizons, 34, 39-48. https://doi.org/10.1016/0007-6813(91)90005-G

Cobb-Walgren, C.J., Beal, C., \& Donthu, N. (1995). Brand equity, brand preferences, and purchase intent. Journal of Advertising, 24(3), 25-40. https://doi.org/10.1080/00913367.1995.10673481

Clarkson, M.B.E. (1995). A shareholder framework for analyzing and evaluating corporate social performance. Academy of Management Review, 20(1), 571-610.

Dua, S., Chahal, R., \& Sharma, A. (2013). Interrelationship of Aaker's customer based brand equity dimensions: offering a model to banking sector. Asian Journal of Management Research, 4(2), 297-307.

Easterby-Smith, M. T. R., \& Lowe, A. (1991). Management research: An introduction, 1.

Fombrun, C., \& Shanley, M. (1990). What's in a name? Reputation building and corporate strategy. Academy of Management Journal, 33(2), 233-58. https://doi.org/10.2307/256324

Fuentes-García, F. J., N ú - ez-Tabales, J. M. \& Veroz-Herradón, R. (2008) Applicability of corporate social responsibility to human resources management: Perspective from Spain. Journal of Business Ethics, 82(1), 27-44. https://doi.org/10.1007/s10551-007-9560-8

Griffin, J.J., \& Mahon, J.F. (1997). The corporate social performance and corporate financial performance debate: 25 years of incomparable research. Business and Society, 36(1), 5-31. https://doi.org/10.1177/000765039703600102

Healy, M., \& Perry, C. (2000). Comprehensive criteria to judge validity and reliability of qualitative research within the realism paradigm. Qualitative market research: An 
international journal, 3(3), 118-126. https://doi.org/10.1108/13522750010333861

Hoeffler, S., \& Keller, K.L. (2002). Building brand equity through corporate societal marketing. Journal of Public Policy and Marketing, 21(1), 78-89. https://doi.org/10.1509/jppm.21.1.78.17600

Holbrook, M. B. (1987). What is consumer research. Journal of consumer research, 14(1). https://doi.org/10.1086/209099

Jian, L., ZhiJian, Y., \& Yongji, X. (2012). Impact of CSR on Brand Equity of Enterprise: A Preliminary Research. Advances in Information Sciences \& Service Sciences, 4(15).

Kumar, V., \& George, M. (2007). Measuring and maximizing customer equity: a critical analysis. Journal of the Academy of Marketing Science, 35(2), 157-171. https://doi.org/10.1007/s11747-007-0028-2

Keller, K. L. (1993). Conceptualizing, measuring and managing customer-based brand equity. Journal of Marketing, 57(1), 1-22. https://doi.org/10.2307/1252054

Keller, K.L. (2003). Strategic Brand Management: Building, Measuring, and Managing Brand Equity, Prentice Hall, Upper Saddle River, NJ.

Lai, C. S., Chiu, C. J., Yang, C. F., \& Pai, D. C. (2010). The effects of corporate social responsibility on brand performance: The mediating effect of industrial brand equity and corporate reputation. Journal of business ethics, 95(3), 457-469. https://doi.org/10.1007/s10551-010-0433-1

Lassar, W., Mittal, B., \& Sharma, A. (1995). Measuring customer-based brand equity. Journal of Consumer Marketing, 12(4), 11-19. https://doi.org/10.1108/07363769510095270

Leone, R.P., Rao, V.R., Keller, K.L., Luo, A.M., McAlister, L., \& Srivastava, R. (2006), 'Linking brand equity to customer equity. Journal of Service Research, 9(2), 125-38. https://doi.org/10.1177/1094670506293563

Margolis, J. D., \& Walsh, J. P. (2003). Misery loves companies: Rethinking social initiatives by business. Administrative science quarterly, 48(2), 268-305. https://doi.org/10.2307/3556659

Maignan, I., \& Ferrell, O. C. (2004). Corporate social responsibility and marketing: An integrative framework. Journal of the Academy of Marketing Science, 32(1), 3-19. https://doi.org/10.1177/0092070303258971

McVea, J. F., \& Freeman, R. E. (2005). A Names-and- Faces Approach to Stakeholder Management. Journal of Management Enquiry, 14(1), 57-69.

McWilliams, A., \& Siegel, D. (2000). Corporate social responsibility: a theory of the firm perspective. Academy of Management Review, 26(1), 117-127.

Newman, I., \& Benz, C. R. (2006). Qualitative-quantitative research methodology: Exploring the interactive continuum. Carbondale, Illinois: Southern Illinois University Press. 
Oliver, C. (1997). Sustainable competitive advantage: Combining institutional and resource-based views. Strategic Management Journal, 18(9), 697-713. https://doi.org/10.1002/(SICI)1097-0266(199710)18:9<697::AID-SMJ909>3.0.CO;2-C

Orlitzky, M., Schmidt, F., \& Rynes, S. (2003). Corporate social and financial performance: A meta-analysis. Organization $\quad$ Studies, $24(3), \quad$ 403-411. https://doi.org/10.1177/0170840603024003910

Pakseresht, A. (2010). Brand equity and corporate responsibility: A review of brand valuation methods. http://www.essays.se/essay/9e20739689/ (accessed 23 January 2016).

Pokorny, G. (1995). Building brand equity and customer loyalty. Electric Perspectives 20.3 http://findarticles.com/p/articles/mi_qa3650/is_199505/ai_n8728762/pg_3/tag=content;col1 (accessed 23 January 2016).

Putnam, R. (1995). Bowling alone: America's declining social capital. Journal of Democracy, 6(1), 65-78. https://doi.org/10.1353/jod.1995.0002

Saunders, R. (2000). CSR: How to get an ethical advantage. http://www.highbeam. com/doc/1G1-156029766.html (accessed 24 January 2016).

Saunders, M., Lewis, P., \& Thornhill, A. (2007). Research Methods for Business Students (4th Ed.) England: Pearson Education Ltd.

Sharp, Z., \& Zaidman, N. (2009). Strategization of CSR. Journal of Business Ethics, 93(1), 51-71. https://doi.org/10.1007/s10551-009-0181-2

Sobh, R., \& Perry, C. (2005). Research design and data analysis in realism research. European Journal of Marketing, 40(11/12), 1194-1209. https://doi.org/10.1108/03090560610702777

Turban, D. B., \& Greening, D. W. (1997). Corporate social performance and organizational attractiveness to prospective employees. Academy of management journal, 40(3), 658-672. https://doi.org/10.2307/257057

Zaman, M. (2014). CSR activities of British American Tobacco Bangladesh. 